\title{
A comparison of nitrogen utilization and urea metabolism between Tibetan and fine-wool sheep ${ }^{1}$
}

\author{
J. W. Zhou, \\ L. M. Ding, $\dagger+$ H. C. Wang, $* \dagger$ Q. Qiu, $\$$ Z. P. Li, \# and R. J. Long, $* \dagger+2$ \\ *State Key Laboratory of Grassland and Agro-Ecosystems, College of Pastoral Agriculture Science and Technology, \\ Lanzhou University, Lanzhou 730000, China; †International Centre for Tibetan Plateau Ecosystem Management, \\ Lanzhou University, Lanzhou 730000, China; $\$$ School of Life Sciences, Lanzhou University, Lanzhou 730000, China; \\ $\S$ Department of Animal Sciences and Industry, Kansas State University, Manhattan 66506; and \#Key Laboratory of Petroleum \\ Resources of Gansu Province, Institute of Geology and Geophysics, Chinese Academy of Sciences, Lanzhou 730000, China
}

\begin{abstract}
To study metabolic adaptation to harsh foraging conditions, an experiment was conducted to characterize and quantify $\mathrm{N}$ utilization efficiency and urea metabolism in Tibetan and fine-wool sheep fed 4 levels of dietary $\mathrm{N}(11.0,16.7,23.1$, and $29.2 \mathrm{~g} \mathrm{~N} / \mathrm{kg}$ $\mathrm{DM}$ ) in 2 concurrent $4 \times 4$ Latin square designs. Urea kinetics were determined using continuous intrajugular infusions of ${ }^{15} \mathrm{~N}^{15} \mathrm{~N}$-urea. Urinary excretions of total $\mathrm{N}$ and urea $\mathrm{N}$ increased linearly $(P<0.001)$ with dietary $\mathrm{N}$ and were not different between breeds $(P \geq 0.37)$. Fecal $\mathrm{N}$ excretion increased with dietary $\mathrm{N}$ for Tibetan sheep but not for fine-wool sheep (linear dietary $\mathrm{N} \times$ breed; $P<0.05$ ). Nitrogen retention (both amount per day and percentage of $\mathrm{N}$ intake) increased with increasing dietary $\mathrm{N}$ concentration $(P<0.001)$, and the rates of increase were greater in fine-wool than in Tibetan sheep (linear dietary $\mathrm{N} \times$ breed and cubic dietary $\mathrm{N} \times$ breed; $P<0.05)$. In Tibetan sheep, $\mathrm{N}$ retention as a percentage of intake was greatest for diets containing $16.7 \mathrm{~g} \mathrm{~N} / \mathrm{kg}$ $\mathrm{DM}$, whereas it was maximal for fine-wool sheep when the diet contained $23.1 \mathrm{~g} \mathrm{~N} / \mathrm{kg} \mathrm{DM}$. Urea $\mathrm{N}$ entry rate, urea $\mathrm{N}$ recycled to the gastrointestinal tract (GIT), and urea $\mathrm{N}$ returned to the ornithine cycle all increased with

dietary $\mathrm{N}(P<0.05)$, and all were greater in Tibetan than fine-wool sheep for the $11.0 \mathrm{~g} \mathrm{~N} / \mathrm{kg} \mathrm{DM}$ diet but were greater in fine-wool than Tibetan sheep for the diet with $29.2 \mathrm{~g} \mathrm{~N} / \mathrm{kg}$ DM (linear dietary $\mathrm{N} \times$ breed; $P<0.05$ ). Urea $\mathrm{N}$ excreted in feces, both amount and fraction of GIT entry rate, was less in Tibetan than finewool sheep for the 11.0 and $16.7 \mathrm{~g} \mathrm{~N} / \mathrm{kg} \mathrm{DM}$ diets but similar for diets with 23.1 or $29.2 \mathrm{~g} \mathrm{~N} / \mathrm{kg} \mathrm{DM}$ (linear dietary $\mathrm{N} \times$ breed; $P<0.01$ ). For the lowest-protein diet, the fraction of urea $\mathrm{N}$ production recycled to the GIT was greater in the Tibetan than fine-wool sheep ( $88 \%$ vs. $82 \%$ ), but for the diet with $29.2 \mathrm{~g} \mathrm{~N} / \mathrm{kg} \mathrm{DM}$ it was greater for fine-wool than Tibetan sheep (46\% vs. $39 \%$; linear dietary $\mathrm{N} \times$ breed; $P<0.05$ ). Plasma urea $\mathrm{N}$ increased more rapidly in response to increasing dietary $\mathrm{N}$ concentration for fine-wool sheep than for Tibetan sheep (linear dietary $\mathrm{N} \times$ breed; $P<0.05$ ). Urea tubular load and the amount and percentage of urea reabsorbed by the kidney were greater in Tibetan than fine-wool sheep $(P<0.05)$. These results suggest that Tibetan sheep have mechanisms that allow them to utilize $\mathrm{N}$ more efficiently than the fine-wool sheep when dietary $\mathrm{N}$ is inadequate.
\end{abstract}

Key words: adaptation, dietary nitrogen utilization, Qinghai-Tibetan Plateau, Tibetan sheep, urea recycling

(C) 2015 American Society of Animal Science. All rights reserved.

J. Anim. Sci. 2015.93:3006-3017 doi:10.2527/jas2014-8865

\section{INTRODUCTION}

\footnotetext{
${ }^{1}$ This work was supported by grants from the National Nature Science Foundation of China, project 31170378. The authors thank Y. Zhang for analytical help and D. L. Liu for his assistance in sample collections.

${ }^{2}$ Corresponding author: longrj@1zu.edu.cn

Received December 31, 2014.

Accepted March 13, 2015.
}

The Qinghai-Tibetan Plateau is known as the "third pole" of the world because it is characterized by high altitude, severe cold, low oxygen level, strong UV radiation, a short growing season, and deficiencies in feed supply (Gerald et al., 2003; Long et al., 
2004; Long et al., 2005). Tibetan sheep and yaks are the 2 major indigenous ruminants that inhabit this harsh environment, living at an altitude of 3,000 to $5,000 \mathrm{~m}$. The fine-wool sheep introduced to this region were obtained by crossbreeding among Caucasian, Xinjiang fine-wool, Saarland fine-wool, Mongolian, and Tibetan sheep in the 1980s. Generally, Tibetan sheep and yaks are under the traditional grazing management by Tibetan herdsmen and tend to experience $\mathrm{N}$ deficiency during the long cold season (Long et al., 2004).

The amount of urea produced by the liver exceeds that eliminated in the urine (Reynolds et al., 1991; Lobley et al., 2000), indicating the existence of urea recycling. Indeed, if dietary intake of $\mathrm{N}$ is insufficient, ruminants regulate $\mathrm{N}$ metabolism (Harmeyer and Martens, 1980; Muscher et al., 2010) to enhance urea $\mathrm{N}$ recycling and kidney urea $\mathrm{N}$ reabsorption rates (Lapierre and Lobley, 2001).

Yaks have been demonstrated to have mechanisms for survival in the harsh environment of the QinghaiTibetan Plateau (Wang et al., 2009; Shao et al., 2010). Tibetan sheep have been living in the same terrain for several thousand years and thus may have mechanisms leading to better $\mathrm{N}$ use compared to the more recently introduced fine-wool sheep.

Our objectives were to characterize whole-body $\mathrm{N}$ retention and urea kinetics in growing Tibetan and fine-wool sheep offered forage-concentrate diets with varying $\mathrm{N}$ concentrations.

\section{MATERIALS AND METHODS}

\section{Animals and Diets}

The experiment was conducted from November 2010 to March 2011 at the Wushaoling Yak Research Facility $\left(37^{\circ} 12.4^{\prime} \mathrm{N}, \quad 102^{\circ} 51.7^{\prime} \mathrm{E}\right.$, altitude 3,154 $\mathrm{m}$, located in the northeast of the Qinghai-Tibetan Plateau) of the International Centre for Tibetan Plateau Ecosystem Management, Lanzhou University, Lanzhou, China. The Animal Ethics Committee of Gansu Province, China, approved the experimental protocols. During a 30-d adaptation before the start of the experiment, the sheep were familiarized with the experimental procedures and urine collection apparatus as well as with the experimental staff working close to them. Throughout the experiment, the average indoor temperature was $4^{\circ} \mathrm{C}$, and relative humidity was $76 \%$. Eight 20- to 24-mo-old castrated male sheep (4 Tibetan sheep, initial BW $50 \pm 3 \mathrm{~kg}$; 4 fine-wool sheep, initial BW $48 \pm 2 \mathrm{~kg}$ ) were used in 2 concurrent $4 \times 4$ Latin square designs. The sheep were individually housed in metabolism crates with ad libitum access to water. They were fed $990 \mathrm{~g} \mathrm{DM} / \mathrm{d}$ (approximately
Table 1. Ingredient and chemical composition of experimental sheep diets

\begin{tabular}{lrrrr}
\hline \hline & \multicolumn{4}{c}{ Dietary N, g/kg DM } \\
\cline { 2 - 5 } Item & 11.0 & 16.7 & 23.1 & 29.2 \\
\hline Ingredient, \% DM & 37.0 & 37.0 & 37.0 & 37.0 \\
$\quad$ Corn stover & 18.0 & 18.0 & 18.0 & 18.0 \\
Highland barley straw & 30.0 & 20.0 & 10.0 & 0.0 \\
Corn & 12.0 & 12.0 & 12.0 & 12.0 \\
Corn starch & 0.0 & 7.0 & 15.0 & 22.0 \\
Soybean meal & 0.0 & 3.0 & 5.0 & 8.0 \\
Corn protein powder & 1.0 & 1.0 & 1.0 & 1.0 \\
Calcium hydrophosphate & 1.0 & 1.0 & 1.0 & 1.0 \\
Sodium chloride & 1.0 & 1.0 & 1.0 & 1.0 \\
Commercial premix ${ }^{1}$ & & & & \\
Chemical composition, \% DM & 6.9 & 10.4 & 14.4 & 18.2 \\
CP & & 56.5 & 55.2 & 54.1 \\
NDF & 57.1 & 5.0 & 24.6 & 25.1 \\
ADF & 23.5 & 24.1 & 0.8 & 0.8 \\
Ether extract & 0.7 & 0.8 & 8.1 & 8.4 \\
Ash & 7.6 & 7.8 & \\
\hline
\end{tabular}

${ }^{1}$ Composition: $\mathrm{Ca}, 28 \%$; P, 19.4\%; Cu, 1,340 mg/kg; Fe, 1,680 mg/kg; Mn 2,100 mg/kg; Zn, 5,160 mg/kg; Se, 18 mg/kg; Co, 110 mg/kg; I, 95 mg/kg.

${ }^{2}$ Calculated as $\mathrm{N} \times 6.25$.

$2 \%$ of $\mathrm{BW} / \mathrm{d})$, receiving half at $0800 \mathrm{~h}$ and the other half at $1800 \mathrm{~h}$ throughout the experiment. A preliminary feeding test indicated that this daily ration would be completely consumed, and no orts were observed during the experiment. The diet (shown in Table 1) was composed of $37 \%$ corn stover, $18 \%$ highland barley straw, and $45 \%$ concentrate, and it was formulated with 4 different levels of $\mathrm{N}(11.0,16.7,23.1$, or $29.2 \mathrm{~g}$ $\mathrm{N} / \mathrm{kg}$ DM) by replacing corn with soybean meal and corn protein powder. The $4 \mathrm{~N}$ levels were designed to simulate the daily $\mathrm{N}$ intake of Tibetan sheep in the different seasons in a year (Dan et al., 2009). The diets were formulated to be isocaloric at 1.2 times the estimated digestible energy requirement for maintenance (114.7 kcal $/ \mathrm{kg} \mathrm{BW}^{0.75}$ daily) and to contain similar concentrations of NDF. The diet with $11.0 \mathrm{~g} \mathrm{~N} / \mathrm{kg}$ $\mathrm{DM}$ was projected to provide less $\mathrm{N}$ than required for maintenance (NRC, 1985).

\section{Experimental Procedure and Sampling}

The experiment procedures were mainly according to those described by Lobley et al. (2000) and Huntington et al. (2009). The protocol consisted of 4 periods, each lasting $21 \mathrm{~d}$, with $15 \mathrm{~d}$ for dietary adaptation (Marini and Van Amburgh, 2003) and $6 \mathrm{~d}$ for collection of feces and urine. Body weight was measured on the first and last days of each period before the $0800 \mathrm{~h}$ feeding. On d 14, the metabolism crates were thoroughly cleaned in preparation for complete collection of fecal and urinary outputs. A clean tray was positioned behind 
each metabolism crate to collect feces. Funnel-shaped latex bags were fixed under the belly of the sheep by 4 elastic belts joined at the 4 top corners of the bag. A latex tube was connected to the bottom of the bag to transfer the urine into a plastic vessel under the metabolism crate containing sufficient $9 \mathrm{M} \mathrm{H}_{2} \mathrm{SO}_{4}$ to reduce the $\mathrm{pH}$ to less than 2.5. On $\mathrm{d} 15$, indwelling catheters were inserted in the left and right external jugular veins of the sheep for isotope infusions and blood sampling.

Beginning on $\mathrm{d} 18$, animals were infused intrajugularly for $56 \mathrm{~h}$ with a stable ${ }^{15} \mathrm{~N}^{15} \mathrm{~N}$-urea isotope (99.24 atom $\%{ }^{15} \mathrm{~N}$, Shanghai Chemical Research Inst., Shanghai, China) prepared in sterile $0.15 \mathrm{M} \mathrm{NaCl}$. Isotope infusion rate was $30 \mathrm{~mL} / \mathrm{h}$ using a peristaltic pump (BT100-1L, Baoding Constant-flow pump Corp., Baoding, China), corresponding to a ${ }^{15} \mathrm{~N}^{15} \mathrm{~N}$ urea infusion rate of $0.1374 \mathrm{mmol}$ urea $\mathrm{N} / \mathrm{h}$, which was predicted to enrich the ${ }^{15} \mathrm{~N}^{15} \mathrm{~N}$-urea concentration by 0.15 to 0.25 molar percent excess (MPE) at plateau for the diet containing $29.2 \mathrm{~g} \mathrm{~N} / \mathrm{kg}$ DM diet after 48 to $56 \mathrm{~h}$ of infusion (Lobley et al., 2000).

Feces and urine were sampled before isotope infusion to establish background ${ }^{15} \mathrm{~N}$ enrichment and then were sampled at 24 and $36 \mathrm{~h}$ as well as every $2 \mathrm{~h}$ from 48 to $56 \mathrm{~h}$ after the start of infusion. Subsamples of urine were frozen and stored for later analysis of urea $\mathrm{N}$ concentration and enrichment with ${ }^{15} \mathrm{~N}^{15} \mathrm{~N}$-urea and ${ }^{15} \mathrm{~N}^{14} \mathrm{~N}$-urea; the means of values between 48 and 56 h (the steady plateau, Fig. 1) were used to calculate urea kinetics. Feces and urine were collected and weighed daily on d 16 to 21 before the $0800 \mathrm{~h}$ feeding. Subsamples $(10 \%$ of daily urine and $15 \%$ of daily feces) were retained. The fecal subsamples were combined for each period, and the urine subsamples were mixed daily and stored at $-20^{\circ} \mathrm{C}$ pending analysis.

Blood was sampled on d 21 before the morning feeding and also at 2-h intervals after feeding until $1600 \mathrm{~h}$. Blood was collected from the jugular vein through the indwelling catheters into Vacutainer tubes containing heparin (Shanghai Kehua Bio-engineering Co. Ltd., Shanghai, China), held at $2^{\circ} \mathrm{C}$ to $6^{\circ} \mathrm{C}$, and centrifuged at $1,200 \times g$ for $15 \mathrm{~min}$ at $4^{\circ} \mathrm{C}$ within $1 \mathrm{~h}$ after collection. Plasma was stored at $-20^{\circ} \mathrm{C}$ for subsequent determination of urea $\mathrm{N}$ and creatinine concentrations.

\section{Sample Analysis}

All feed and fecal samples were freeze-dried using a FreeZone-12L freeze dryer (Labconco Corp., Kansas City, MO) for $7 \mathrm{~d}$, then ground to pass through a 1-mm screen, and stored at room temperature in sealed plastic bags until further analysis. Freeze-dried subsamples were dried in a forced-air oven at $105^{\circ} \mathrm{C}$ for $4 \mathrm{~h}$ to a constant weight to determine DM. The $\mathrm{N}$ content of feed, feces, and urine was determined using the microKjeldahl N method (AOAC, 1990). Ether extract was analyzed as weight reduction of the dry sample on extraction with diethyl ether in a Soxhlet extraction apparatus (Soxtec 2050, FOSS, Hillerød, Denmark) for $6 \mathrm{~h}$, and ash was determined as residue following complete combustion in a muffle furnace at $600^{\circ} \mathrm{C}$ for $6 \mathrm{~h}$ (AOAC, 1990). The NDF (assayed without heat-stable amylase and expressed inclusive of residual ash) and ADF (expressed inclusive of residual ash) of feed was analyzed using the method of Van Soest et al. (1991). Plasma and urine creatinine were measured using reversed-phase HPLC (Balcells et al., 1992).

Urea $\mathrm{N}$ in plasma and urine was determined using the diacetylmonoxime method described by Marsh et al. (1957) with a spectrophotometer(U-2900, Hitachi, Tokyo, Japan). Urinary urea was isolated with a cation-exchange resin (AG 50W-X8, 100- to 200-mesh hydrogen form; Bio-Rad, Richmond, CA) using the method described by Wickersham et al. (2008a) before the ${ }^{15} \mathrm{~N}$ enrichment was measured. The cation exchange resin was used to fill in the glass column (15 cm long and $1.3 \mathrm{~cm}$ diam.), then rinsed with $10 \mathrm{~mL}$ of $1 \mathrm{mM} \mathrm{NaOH}$, rinsed twice with $10 \mathrm{~mL}$ of $\mathrm{N}$-free water, rinsed twice with $10 \mathrm{~mL}$ of $1 \mathrm{mM} \mathrm{HCl}$, and rinsed twice with $10 \mathrm{~mL}$ of $\mathrm{N}$-free water as described by Archibeque et al. (2001). Then, $5 \mathrm{~mL}$ of urine were added to the column, kept for $5 \mathrm{~min}$, and rinsed with $5 \mathrm{~mL}$ of $\mathrm{N}$-free water with the effluent discarded; the column was then rinsed with $5 \mathrm{~mL}$ of $\mathrm{N}$-free water, with the effluent retained. The concentration of urea $\mathrm{N}$ and ammonia $\mathrm{N}$ in the retained effluent was measured as described by Marsh et al. (1957) and Broderick and Kang (1980), respectively. The final concentration of urinary urea $\mathrm{N}$ was adjusted to $12 \mathrm{mM}$. The generation of ${ }^{28} \mathrm{~N}_{2},{ }^{29} \mathrm{~N}_{2}$, and ${ }^{30} \mathrm{~N}_{2}$ from the monomolecular reactions of urea in the isolated and adjusted solutions was assessed strictly according to the methods described by Marini and Attene-Ramos (2006). The enrichment of these gases was measured at the Key Laboratory of Petroleum Resources of Gansu Province (Chinese Academy of Sciences, Lanzhou, China) using a Thermo Finnigan DELTA ${ }^{\text {plus }}$ XP mass spectrometer (Thermo Finnigan, San Jose, CA). The gas was determined within $4 \mathrm{~h}$ of converting the prepared urea $\mathrm{N}$ to $\mathrm{N}_{2}$, as recommended by Marini and Attene-Ramos (2006). With the enriched standards (12 mM urea with ${ }^{15} \mathrm{~N}_{2}$ enrichments of $0.1,0.2$, and 0.3 atom percent excess), the rate of nonmonomolecular reactions to form ${ }^{15} \mathrm{~N}^{14} \mathrm{~N}$ gas was $5.1 \%$, which is similar to the values of $5.0 \%$ and $4.68 \%$ found by Marini and Van Amburgh (2003) and Sarraseca et al. (1998), respectively. Fecal ${ }^{15} \mathrm{~N}$ enrichment was analyzed in continuous-flow mode using a system for isotope ratio elemental analysis (Flash EA1112, Thermo Electron SPA; DELTAplus XP, Thermo Finnigan, San Jose, CA). 
(a)
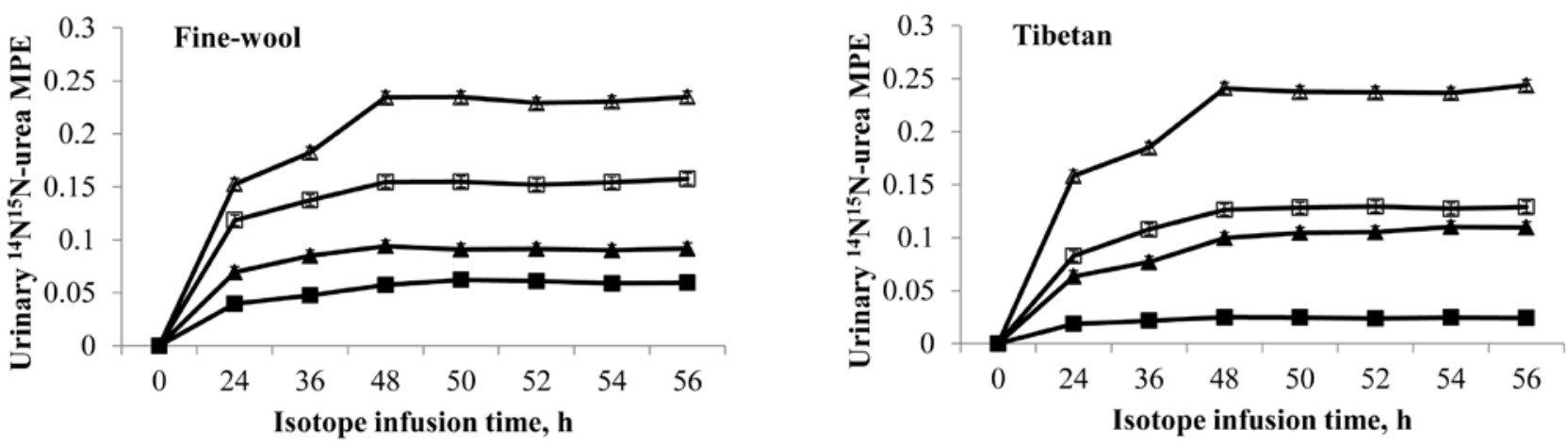

(b)
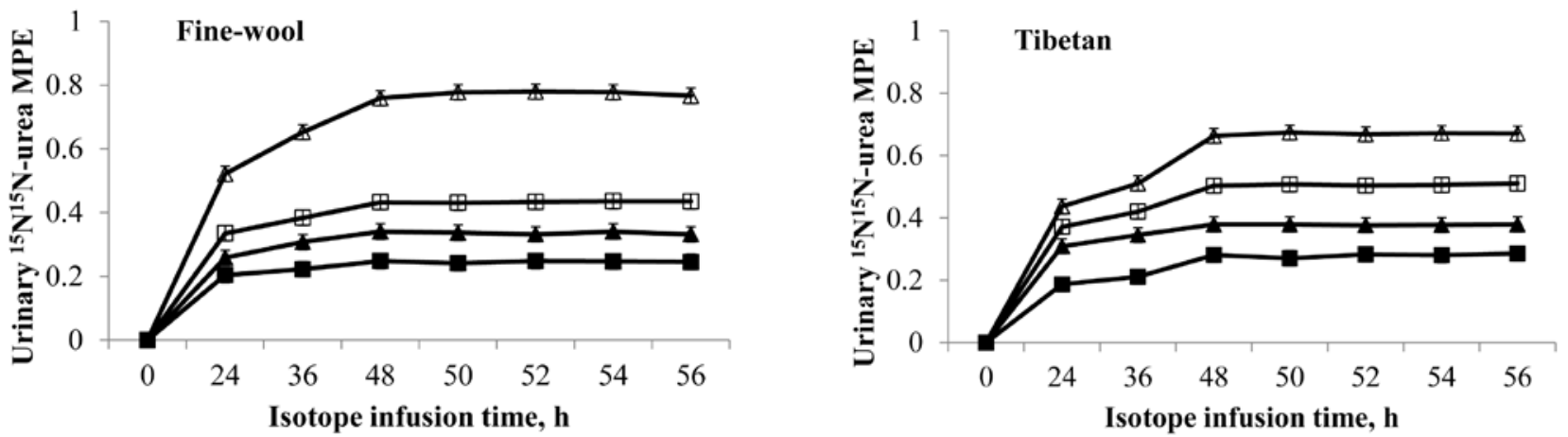

(c)
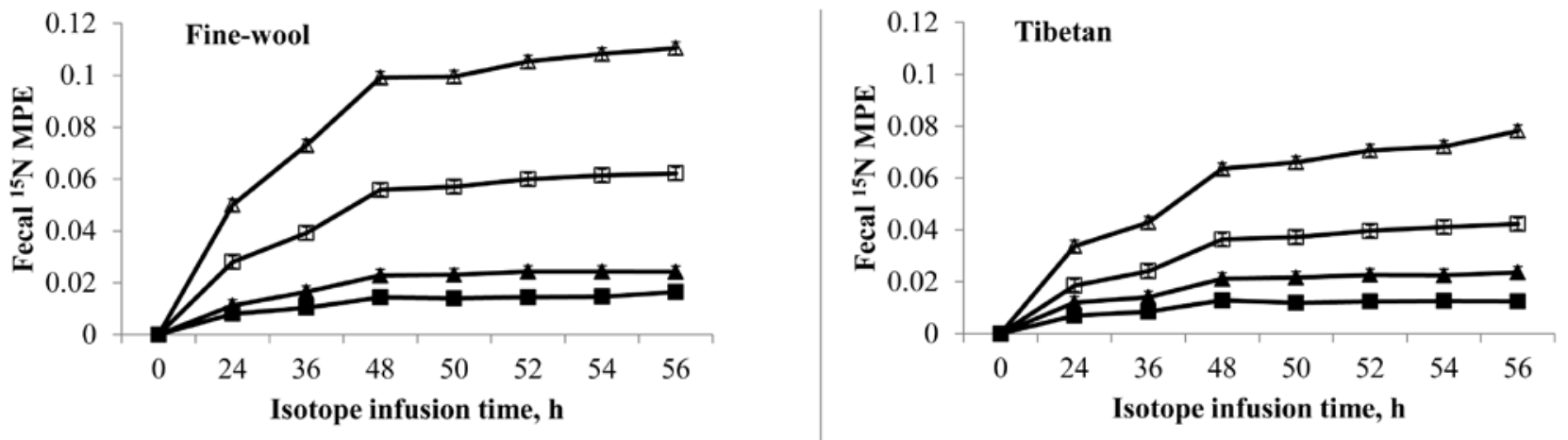

Figure 1. (a) Urinary ${ }^{14} \mathrm{~N}^{15} \mathrm{~N}$-urea, (b) urinary ${ }^{15} \mathrm{~N}^{15} \mathrm{~N}$-urea, and (c) fecal ${ }^{15} \mathrm{~N}$ molar percent access (MPE) during a 56 -h intravascular infusion of ${ }^{15} \mathrm{~N}^{15} \mathrm{~N}$-urea in the fine-wool and Tibetan sheep offered diets with different $\mathrm{N}$ concentrations (open triangles $=11.0 \mathrm{~g} \mathrm{~N} / \mathrm{kg}$ DM, open squares $=16.7 \mathrm{~g} \mathrm{~N} / \mathrm{kg}$ $\mathrm{DM}$, solid triangles $=23.1 \mathrm{~g} \mathrm{~N} / \mathrm{kg} \mathrm{DM}$, solid squares $=29.2 \mathrm{~g} \mathrm{~N} / \mathrm{kg} \mathrm{DM}$ ). Over the period of 48 to $56 \mathrm{~h}$ of isotope infusion, for urinary ${ }^{14} \mathrm{~N}^{15} \mathrm{~N}-$ urea, breed $P=0.53$, dietary $\mathrm{N} P<0.001$, and sampling time $P=0.40$; for urinary ${ }^{15} \mathrm{~N}^{15} \mathrm{~N}$-urea, breed $P=0.75$, dietary $\mathrm{N} P<0.001$, and sampling time $P=0.43$; and for fecal $15^{\mathrm{N}}$, breed $P=0.05$, dietary N $P<0.001$, and sampling time $P=0.07$.

\section{Calculation of Urea Kinetics,}

\section{Glomerular Filtration Rate, and Urea Pool Size}

Urea kinetics were calculated according to the model established by Lobley et al. (2000). Urea and creatinine clearance by the kidney were calculated as the rate of urea or creatinine excretion in the urine divided by the concentration of the corresponding metabolite in the plasma. Glomerular filtration rate was defined as equal to renal creatinine clearance (Wang et al., 2009), and renal urea $\mathrm{N}$ tubular load was calculated as the product of plasma urea $\mathrm{N}$ concentration and glomerular filtration rate. The urea pool size and turnover time were calculated from the urea space and urea concentration in the urea pool according to Harmeyer and Martens (1980), assuming the urea space to be $48.7 \%$ of BW (Bartle et al., 1988) and the concentration of the urea pool to be equal to plasma urea N (PUN; Marini and Van Amburgh, 2003). Turnover time was estimated from urea $\mathrm{N}$ pool size and the rate of urea $\mathrm{N}$ production, assuming steady state conditions (Guo et al., 2012). 
Table 2. Effect of dietary $\mathrm{N}$ intake and breed on $\mathrm{N}$ balance in Tibetan sheep (T) vs. fine-wool sheep (F)

\begin{tabular}{|c|c|c|c|c|c|c|c|c|c|c|}
\hline \multirow[b]{2}{*}{ Item } & \multirow[b]{2}{*}{ Breed } & \multicolumn{4}{|c|}{ Dietary N, g/kg DM } & \multirow[b]{2}{*}{ SEM } & \multicolumn{4}{|c|}{$P$-value ${ }^{1}$} \\
\hline & & 11.0 & 16.7 & 23.1 & 29.2 & & Breed & $\mathrm{N}-\mathrm{L}$ & $\mathrm{N}-\mathrm{Q}$ & $\mathrm{N}-\mathrm{C}$ \\
\hline \multirow[t]{2}{*}{ Total $N$ intake, $g / d$} & $\mathrm{~F}$ & 10.9 & 16.5 & 22.9 & 28.9 & 0.01 & 0.78 & $<0.001$ & 0.23 & 0.64 \\
\hline & $\mathrm{T}$ & 10.9 & 16.5 & 22.9 & 28.9 & & & $0.74^{\mathrm{x}}$ & $0.46^{\mathrm{x}}$ & $0.33^{x}$ \\
\hline \multirow[t]{2}{*}{ Digestible $\mathrm{N}$ intake, $\mathrm{g} / \mathrm{d}$} & $\mathrm{F}$ & $4.9^{\mathrm{a}}$ & $10.2^{\mathrm{a}}$ & $17.2^{\mathrm{b}}$ & $23.1^{\mathrm{b}}$ & 0.19 & 0.97 & $<0.001$ & 0.19 & 0.15 \\
\hline & $\mathrm{T}$ & $5.4^{\mathrm{b}}$ & $10.9^{\mathrm{b}}$ & $16.6^{\mathrm{a}}$ & $22.6^{\mathrm{a}}$ & & & $0.03^{\mathrm{x}}$ & $0.96^{\mathrm{x}}$ & $0.09^{\mathrm{x}}$ \\
\hline \multirow[t]{2}{*}{$\mathrm{N}$ in feces, $\mathrm{g} / \mathrm{d}$} & $\mathrm{F}$ & $6.0^{\mathrm{b}}$ & $6.3^{\mathrm{b}}$ & $5.6^{\mathrm{a}}$ & $5.8^{\mathrm{a}}$ & 0.19 & 0.97 & 0.32 & 0.63 & 0.78 \\
\hline & $\mathrm{T}$ & $5.5^{\mathrm{a}}$ & $5.6^{\mathrm{a}}$ & $6.3^{\mathrm{b}}$ & $6.3^{\mathrm{b}}$ & & & $0.03^{\mathrm{x}}$ & $0.96^{\mathrm{x}}$ & $0.09^{\mathrm{x}}$ \\
\hline \multirow[t]{2}{*}{ Urinary $\mathrm{N}, \mathrm{g} / \mathrm{d}$} & $\mathrm{F}$ & 3.0 & 6.3 & 9.1 & 14.1 & 0.55 & 0.56 & $<0.001$ & 0.06 & 0.94 \\
\hline & $\mathrm{T}$ & 2.7 & 5.6 & 10.6 & 14.7 & & & $0.18^{\mathrm{x}}$ & $0.72^{\mathrm{x}}$ & $0.11^{\mathrm{x}}$ \\
\hline \multirow[t]{2}{*}{ Urinary urea $\mathrm{N}, \mathrm{g} / \mathrm{d}$} & $\mathrm{F}$ & 1.2 & 4.1 & 6.9 & 11.0 & 0.43 & 0.37 & $<0.001$ & 0.05 & 0.38 \\
\hline & $\mathrm{T}$ & 0.9 & 3.5 & 6.4 & 10.6 & & & $0.91^{\mathrm{x}}$ & $0.51^{\mathrm{x}}$ & $0.95^{\mathrm{x}}$ \\
\hline \multirow[t]{2}{*}{ Urinary ammonia $\mathrm{N}, \mathrm{mg} / \mathrm{d}$} & $\mathrm{F}$ & 16.4 & 27.2 & 26.8 & 27.7 & 4.63 & 0.53 & $<0.01$ & 0.67 & 0.55 \\
\hline & $\mathrm{T}$ & 9.0 & 17.7 & 22.7 & 34.1 & & & $0.23^{\mathrm{x}}$ & $0.46^{\mathrm{x}}$ & $0.95^{\mathrm{x}}$ \\
\hline \multirow[t]{2}{*}{$\mathrm{N}$ retention, $\mathrm{g} / \mathrm{d}$} & $\mathrm{F}$ & $2.0^{\mathrm{a}}$ & $3.9^{\mathrm{a}}$ & $8.1^{\mathrm{b}}$ & $9.0^{\mathrm{b}}$ & 0.33 & 0.51 & $<0.001$ & 0.30 & 0.51 \\
\hline & $\mathrm{T}$ & $2.7^{\mathrm{b}}$ & $5.3^{\mathrm{b}}$ & $6.0^{\mathrm{a}}$ & $7.9^{\mathrm{a}}$ & & & $0.03^{\mathrm{x}}$ & $0.77^{\mathrm{x}}$ & $0.03^{\mathrm{x}}$ \\
\hline \multirow[t]{2}{*}{$\mathrm{N}$ retention:total $\mathrm{N}$ intake, $\%$} & $\mathrm{~F}$ & $18.0^{\mathrm{a}}$ & $23.9^{\mathrm{a}}$ & $35.5^{\mathrm{b}}$ & $31.1^{\mathrm{b}}$ & 1.72 & 0.74 & $<0.001$ & $<0.01$ & 0.87 \\
\hline & $\mathrm{T}$ & $24.7^{\mathrm{b}}$ & $31.9^{\mathrm{b}}$ & $26.2^{\mathrm{a}}$ & $27.5^{\mathrm{a}}$ & & & $<0.001^{\mathrm{x}}$ & $0.42^{\mathrm{x}}$ & $<0.01^{\mathrm{x}}$ \\
\hline \multirow[t]{2}{*}{ Urine $\mathrm{N}$ :total $\mathrm{N}$ intake, $\%$} & $\mathrm{~F}$ & 27.2 & 37.8 & 39.8 & 48.8 & 2.32 & 0.80 & $<0.001$ & 0.29 & 0.68 \\
\hline & $\mathrm{T}$ & 24.9 & 34.1 & 46.2 & 50.8 & & & $0.09^{\mathrm{x}}$ & $0.61^{\mathrm{x}}$ & $0.06^{\mathrm{x}}$ \\
\hline \multirow[t]{2}{*}{ Urine $\mathrm{N}$ :digestible $\mathrm{N}$} & $\mathrm{F}$ & $60.1^{\mathrm{b}}$ & $61.6^{\mathrm{b}}$ & $52.8^{\mathrm{a}}$ & $61.0^{\mathrm{a}}$ & 2.47 & 0.63 & $<0.01$ & 0.25 & 0.77 \\
\hline & $\mathrm{T}$ & $51.9^{\mathrm{a}}$ & $51.7^{\mathrm{a}}$ & $63.5^{\mathrm{b}}$ & $64.9^{\mathrm{a}}$ & & & $<0.01^{\mathrm{x}}$ & $0.48^{\mathrm{x}}$ & $<0.01^{\mathrm{x}}$ \\
\hline \multirow[t]{2}{*}{ Urine urea N:total N intake, $\%$} & $\mathrm{~F}$ & 9.9 & 24.7 & 30.1 & 37.1 & 1.43 & 0.35 & $<0.001$ & 0.02 & 0.08 \\
\hline & $\mathrm{T}$ & 8.3 & 21.3 & 27.9 & 36.8 & & & $0.65^{\mathrm{x}}$ & $0.46^{\mathrm{x}}$ & $0.85^{\mathrm{x}}$ \\
\hline \multirow[t]{2}{*}{ Urinary urea N:urine N, \% } & $\mathrm{F}$ & 36.5 & 65.3 & 75.6 & 76.4 & 4.11 & 0.10 & $<0.001$ & $<0.01$ & 0.27 \\
\hline & $\mathrm{T}$ & 33.1 & 59.7 & 62.8 & 72.3 & & & $0.78^{\mathrm{x}}$ & $0.47^{\mathrm{x}}$ & $0.54^{\mathrm{x}}$ \\
\hline
\end{tabular}

\section{Statistical Analyses}

Data were analyzed using the MIXED procedure of SAS 9.2 (SAS Inst. Inc., Cary, NC) according to the following model: $\mathrm{Y}=\mu+\mathrm{P}+\mathrm{A}+\mathrm{N}+\mathrm{B}+(\mathrm{N} \times$ $\mathrm{B})+\mathrm{E}$, where $\mathrm{Y}$ is the dependent variable, $\mu$ is the overall mean, $\mathrm{P}$ is the effect of period, $\mathrm{A}$ is the effect of animal, $\mathrm{N}$ is the effect of dietary $\mathrm{N}$ level, $\mathrm{B}$ is the effect of sheep breed, $\mathrm{N} \times \mathrm{B}$ is the interaction between dietary $\mathrm{N}$ level and sheep breed, and $\mathrm{E}$ is the residual error. Dietary $\mathrm{N}$ level and breed were considered the fixed effects, and experiment animal and period were considered the random effects. Polynomial contrasts for the effect of $\mathrm{N}$ level as well as for the breed $\times \mathrm{N}$ level interactions were used to evaluate treatment effects. Comparisons between breeds within each level of dietary $\mathrm{N}$ were made using $t$ tests when at least 1 contrast assessing the breed $\times$ dietary $\mathrm{N}$ level interaction was significant. These $t$ tests were performed to ensure that interpretations of the contrasts were clear. Differences were considered significant at $P<0.05$, and tendencies were considered at $P<0.10$.

\section{RESULTS}

\section{Nitrogen Balance and Utilization}

As shown in Table 2, the dietary $\mathrm{N}$ intake was increased linearly $(P<0.001)$ from 10.9 to $28.9 \mathrm{~g} / \mathrm{d}$ with no difference between breeds $(P=0.78)$. Digestible $\mathrm{N}$ intake increased at a greater rate in response to increases in dietary $\mathrm{N}$ for fine-wool sheep than for Tibetan sheep (linear dietary $\mathrm{N} \times$ breed; $P<0.05$ ). Urinary excretions of total $\mathrm{N}$, urea $\mathrm{N}$, and ammonia $\mathrm{N}$ were not different between breeds $(P \geq 0.37)$, but fecal $\mathrm{N}$ excretion increased in response to increasing dietary $\mathrm{N}$ for Tibetan sheep but not for fine-wool sheep (linear dietary $\mathrm{N} \times$ breed; $P<0.05$ ).

Significant interactions between breed and diet were detected for the amount of $\mathrm{N}$ retained and the percentage of $\mathrm{N}$ intake retained, where the rate of increase was greater in fine-wool than in Tibetan sheep; the values were greater in Tibetan than in fine-wool sheep fed the 11.0 and $16.7 \mathrm{~g} \mathrm{~N} / \mathrm{kg}$ DM diets, but both parameters were greater in fine-wool than in Tibetan sheep fed the 23.1 and $29.2 \mathrm{~g} \mathrm{~N} / \mathrm{kg}$ DM diets (linear and cubic dietary 
Table 3. Effect of dietary $\mathrm{N}$ intake on urea $\mathrm{N}$ kinetics in Tibetan sheep (T) vs. fine-wool sheep (F)

\begin{tabular}{|c|c|c|c|c|c|c|c|c|c|c|}
\hline \multirow[b]{2}{*}{ Item $^{1}$} & \multirow[b]{2}{*}{ Breed } & \multicolumn{4}{|c|}{ Dietary $\mathrm{N}, \mathrm{g} / \mathrm{kg}$ DM } & \multirow[b]{2}{*}{ SEM } & \multicolumn{4}{|c|}{$P$-value ${ }^{2}$} \\
\hline & & 11.0 & 16.7 & 23.1 & 29.2 & & Breed & $\mathrm{N}-\mathrm{L}$ & N-Q & $\mathrm{N}-\mathrm{C}$ \\
\hline \multirow[t]{2}{*}{$\overline{\mathrm{UER}, \mathrm{g} / \mathrm{d}}$} & $F$ & $6.3^{\mathrm{a}}$ & $11.7^{\mathrm{b}}$ & $15.1^{\mathrm{b}}$ & $21.0^{\mathrm{b}}$ & 0.48 & 0.24 & $<0.001$ & 0.43 & 0.67 \\
\hline & $\mathrm{T}$ & $7.5^{\mathrm{b}}$ & $10.0^{\mathrm{a}}$ & $14.1^{\mathrm{a}}$ & $18.4^{\mathrm{a}}$ & & & $0.05^{\mathrm{x}}$ & $0.76^{\mathrm{x}}$ & $0.41^{\mathrm{x}}$ \\
\hline \multirow[t]{2}{*}{ UUE, g/d } & F & 1.2 & 4.1 & 6.9 & 11.0 & 0.43 & 0.37 & $<0.001$ & 0.05 & 0.38 \\
\hline & $\mathrm{T}$ & 0.9 & 3.5 & 6.4 & 10.6 & & & $0.91^{\mathrm{x}}$ & $0.51^{\mathrm{x}}$ & $0.95^{\mathrm{x}}$ \\
\hline \multirow[t]{2}{*}{ GER, g/d } & $\mathrm{F}$ & $5.1^{\mathrm{a}}$ & $7.7^{\mathrm{b}}$ & $8.2^{\mathrm{a}}$ & $10.3^{\mathrm{b}}$ & 0.51 & 0.40 & $<0.01$ & 0.96 & 0.90 \\
\hline & $\mathrm{T}$ & $6.6^{\mathrm{b}}$ & $6.5^{\mathrm{a}}$ & $7.7^{\mathrm{a}}$ & $7.7^{\mathrm{a}}$ & & & $0.04^{\mathrm{x}}$ & $0.89^{\mathrm{x}}$ & $0.38^{\mathrm{x}}$ \\
\hline \multirow[t]{2}{*}{ ROC, g/d } & F & $1.5^{\mathrm{a}}$ & $3.2^{\mathrm{b}}$ & $3.4^{\mathrm{a}}$ & $4.4^{\mathrm{b}}$ & 0.22 & 0.02 & $<0.001$ & 0.06 & 0.70 \\
\hline & $\mathrm{T}$ & $2.1^{\mathrm{b}}$ & $2.2^{\mathrm{a}}$ & $3.2^{\mathrm{a}}$ & $1.7^{\mathrm{a}}$ & & & $<0.01^{\mathrm{x}}$ & $0.44^{\mathrm{x}}$ & $0.03^{x}$ \\
\hline \multirow[t]{2}{*}{ UFE, $\mathrm{g} / \mathrm{d}$} & F & $0.64^{\mathrm{b}}$ & $0.64^{\mathrm{b}}$ & $0.32^{\mathrm{a}}$ & $0.29^{\mathrm{a}}$ & 0.044 & 0.02 & $<0.001$ & 0.85 & 0.02 \\
\hline & $\mathrm{T}$ & $0.43^{\mathrm{a}}$ & $0.36^{\mathrm{a}}$ & $0.31^{\mathrm{a}}$ & $0.26^{\mathrm{a}}$ & & & $<0.01^{\mathrm{x}}$ & $0.68^{\mathrm{x}}$ & $0.01^{\mathrm{x}}$ \\
\hline \multirow[t]{2}{*}{ UUA, g/d } & F & 3.2 & 3.8 & 4.5 & 5.7 & 0.78 & 0.74 & $<0.01$ & 0.29 & 0.82 \\
\hline & $\mathrm{T}$ & 4.1 & 4.0 & 4.3 & 5.8 & & & $0.59^{\mathrm{x}}$ & $0.63^{x}$ & $0.92^{\mathrm{x}}$ \\
\hline \multirow[t]{2}{*}{ UUE:UER (u) } & F & 0.18 & 0.36 & 0.47 & 0.54 & 0.022 & 0.63 & $<0.001$ & 0.03 & 0.49 \\
\hline & $\mathrm{T}$ & 0.12 & 0.37 & 0.49 & 0.61 & & & $0.04^{\mathrm{x}}$ & $0.98^{\mathrm{x}}$ & $0.72^{\mathrm{x}}$ \\
\hline \multirow[t]{2}{*}{ GER:UER $(1-u)$} & F & $0.82^{\mathrm{a}}$ & $0.64^{\mathrm{a}}$ & $0.53^{\mathrm{a}}$ & $0.46^{\mathrm{b}}$ & 0.022 & 0.63 & $<0.001$ & 0.03 & 0.49 \\
\hline & $\mathrm{T}$ & $0.88^{\mathrm{b}}$ & $0.63^{\mathrm{a}}$ & $0.51^{\mathrm{a}}$ & $0.39^{\mathrm{a}}$ & & & $0.04^{\mathrm{x}}$ & $0.98^{\mathrm{x}}$ & $0.72^{\mathrm{x}}$ \\
\hline \multirow[t]{2}{*}{ ROC:GER (r) } & F & 0.28 & 0.42 & 0.42 & 0.44 & 0.043 & 0.11 & 0.11 & $<0.01$ & 0.22 \\
\hline & $\mathrm{T}$ & 0.30 & 0.33 & 0.47 & 0.24 & & & $0.05^{\mathrm{x}}$ & $0.28^{x}$ & $0.02^{\mathrm{x}}$ \\
\hline \multirow[t]{2}{*}{ UFE:GER (f) } & F & $0.12^{\mathrm{b}}$ & $0.09^{\mathrm{b}}$ & $0.04^{\mathrm{a}}$ & $0.03^{\mathrm{a}}$ & 0.009 & 0.23 & $<0.001$ & 0.29 & 0.36 \\
\hline & $\mathrm{T}$ & $0.07^{\mathrm{a}}$ & $0.05^{\mathrm{a}}$ & $0.05^{\mathrm{a}}$ & $0.05^{\mathrm{a}}$ & & & $<0.001^{\mathrm{x}}$ & $0.72^{\mathrm{x}}$ & $0.21^{\mathrm{x}}$ \\
\hline \multirow[t]{2}{*}{ UUA:GER (a) } & F & 0.60 & 0.49 & 0.54 & 0.53 & 0.043 & 0.07 & 0.80 & $<0.01$ & 0.29 \\
\hline & $\mathrm{T}$ & 0.63 & 0.62 & 0.48 & 0.71 & & & $0.30^{\mathrm{x}}$ & $0.24^{\mathrm{x}}$ & $<0.01^{\mathrm{x}}$ \\
\hline \multicolumn{11}{|c|}{${ }^{\mathrm{a}, \mathrm{b}}$ Within a column, means without a common superscript differ $(P<0.05)$. } \\
\hline
\end{tabular}

$\mathrm{N} \times$ breed; $P<0.05$ ). For fine-wool sheep, the greatest proportion of $\mathrm{N}$ intake was retained when diets contained $23.1 \mathrm{~g} \mathrm{~N} / \mathrm{kg} \mathrm{DM}$, whereas for Tibetan sheep the greatest proportion of $\mathrm{N}$ intake was retained when diets contained $16.7 \mathrm{~g} \mathrm{~N} / \mathrm{kg} \mathrm{DM}$ (Table 2).

The proportion of urinary $\mathrm{N}$ that was urea $\mathrm{N}$ tended to be greater in fine-wool than Tibetan sheep $(P=$ 0.10). No differences between Tibetan and fine-wool sheep were found in the ratios of urinary $\mathrm{N}$ and urinary urea $\mathrm{N}$ to $\mathrm{N}$ intake $(P>0.35)$, and interactions between breed and diet were not significant.

The digestible $\mathrm{N}$ intake, $\mathrm{N}$ retention, elimination of urinary total $\mathrm{N}$, ammonia $\mathrm{N}$, and urinary urea $\mathrm{N}$ increased linearly $(P \leq 0.01)$ as the dietary $\mathrm{N}$ level increased, but fecal $\mathrm{N}$ excretion did not change when the dietary $\mathrm{N}$ varied $(P \geq 0.32)$. The ratios of $\mathrm{N}$ retention to total $\mathrm{N}$ intake, urine $\mathrm{N}$ to total $\mathrm{N}$ intake, urinary urea $\mathrm{N}$ to total $\mathrm{N}$ intake, and urinary urea $\mathrm{N}$ to urinary $\mathrm{N}$ were each increased linearly as dietary $\mathrm{N}$ increased $(P<0.001)$.

\section{Characteristics of Urea Kinetics}

Urinary ${ }^{15} \mathrm{~N}^{15} \mathrm{~N}$-urea and ${ }^{14} \mathrm{~N}^{15} \mathrm{~N}$-urea MPE both reached plateau by $48 \mathrm{~h}$ of infusion (no effect of time between 48 and 56 h; $P \geq 0.40$; Fig. 1). Fecal ${ }^{15} \mathrm{~N}$ enrichment tended to increase over time during the sampling period ( $P=0.07$; Fig. 1$)$, such that fecal urea $\mathrm{N}$ excretion may have been slightly underestimated, which would lead to urea $\mathrm{N}$ for anabolism being slightly overestimated.

The urea entry rate (UER) was greater in the Tibetan sheep at the lowest level of dietary N, whereas it was greater in the fine-wool sheep for the other 3 diets (linear dietary $\mathrm{N} \times$ breed; $P<0.05$; Table 3 ). The gastrointestinal tract (GIT) entry rate (GER) and urea return to ornithine cycle (ROC) were greater in Tibetan than fine-wool sheep receiving the $11.0 \mathrm{~g} \mathrm{~N} / \mathrm{kg}$ diet but lower for Tibetan than fine-wool sheep for the diets with 16.7 and $29.2 \mathrm{~N} \mathrm{~g} / \mathrm{kg} \mathrm{DM}$, with no difference between breeds for $23.1 \mathrm{~N} \mathrm{~g} / \mathrm{kg}$ DM (linear dietary $\mathrm{N} \times$ breed; $P<0.05)$. There were no differences between breeds $(P \geq 0.37)$ in urinary urea elimination (UUE) and urea used for anabolism (UUA), and no interactions between breed and diet were observed for those criteria $(P>$ 0.51). The urea $\mathrm{N}$ excreted in feces (UFE) and UFE as a fraction of GER were lower in the Tibetan than finewool sheep fed the 11.0 and $16.7 \mathrm{~g} \mathrm{~N} / \mathrm{kg}$ DM diets, but no difference was observed for the other 2 diets (linear 
Table 4. Effect of dietary $\mathrm{N}$ intake on creatinine clearance and renal urea $\mathrm{N}$ reabsorption in Tibetan (T) and finewool (F) sheep

\begin{tabular}{|c|c|c|c|c|c|c|c|c|c|c|}
\hline \multirow[b]{2}{*}{ Item } & \multirow[b]{2}{*}{ Breed } & \multicolumn{4}{|c|}{ Dietary $\mathrm{N}, \mathrm{g} / \mathrm{kg}$ DM } & \multirow[b]{2}{*}{ SEM } & \multicolumn{4}{|c|}{$P$-value ${ }^{1}$} \\
\hline & & 11.0 & 16.7 & 23.1 & 29.2 & & Breed & N-L & N-Q & $\mathrm{N}-\mathrm{C}$ \\
\hline \multirow{2}{*}{$\begin{array}{l}\text { Urinary creatinine excretion, } \\
\mu \mathrm{mol} \cdot \mathrm{kg}^{-1} \mathrm{BW}^{0.75} \cdot \mathrm{d}^{-1}\end{array}$} & $\mathrm{~F}$ & 435 & 458 & 427 & 470 & 25.3 & 0.04 & 0.98 & 0.42 & 0.47 \\
\hline & $\mathrm{T}$ & 613 & 583 & 557 & 597 & & & $0.56^{\mathrm{x}}$ & $0.66^{\mathrm{x}}$ & $0.79^{\mathrm{x}}$ \\
\hline \multirow{2}{*}{$\begin{array}{l}\text { Plasma creatinine, } \\
\mu M\end{array}$} & $\mathrm{~F}$ & 74.7 & 73.4 & 68.7 & 70.1 & 5.33 & 0.43 & $<0.01$ & 0.52 & 0.70 \\
\hline & $\mathrm{T}$ & 88.6 & 79.5 & 72.7 & 68.2 & & & $0.06^{\mathrm{x}}$ & $0.87^{\mathrm{x}}$ & $0.71^{\mathrm{x}}$ \\
\hline \multirow{2}{*}{$\begin{array}{l}\text { Creatinine clearance, } \\
\mathrm{L} / \mathrm{kg} \mathrm{BW}^{0.75} \text { per day }\end{array}$} & F & 6.1 & 6.4 & 6.4 & 6.9 & 0.78 & 0.09 & 0.09 & 0.67 & 0.56 \\
\hline & $\mathrm{T}$ & 7.1 & 7.7 & 7.7 & 9.1 & & & $0.43^{\mathrm{x}}$ & $0.81^{\mathrm{x}}$ & $0.82^{x}$ \\
\hline \multirow{2}{*}{$\begin{array}{l}\text { Plasma urea } \mathrm{N}, \\
\mathrm{m} M\end{array}$} & F & $11.4^{\mathrm{a}}$ & $13.9^{\mathrm{a}}$ & $18.8^{\mathrm{b}}$ & $19.2^{\mathrm{a}}$ & 1.24 & 0.23 & $<0.001$ & 0.98 & 0.88 \\
\hline & $\mathrm{T}$ & $15.5^{\mathrm{b}}$ & $17.3^{\mathrm{b}}$ & $16.3^{\mathrm{a}}$ & $20.4^{\mathrm{a}}$ & & & $0.04^{\mathrm{x}}$ & $0.29^{\mathrm{x}}$ & $0.10^{\mathrm{x}}$ \\
\hline \multirow{2}{*}{$\begin{array}{l}\text { Urea N tubular load, } \\
\mathrm{g} / \mathrm{kg} \mathrm{BW}^{0.75} \text { per day }\end{array}$} & $\mathrm{F}$ & 1.0 & 1.2 & 1.7 & 1.8 & 0.23 & 0.04 & $<0.001$ & 0.56 & 0.66 \\
\hline & $\mathrm{T}$ & 1.5 & 1.8 & 1.7 & 2.6 & & & $0.87^{x}$ & $0.34^{x}$ & $0.17^{x}$ \\
\hline \multirow{2}{*}{$\begin{array}{l}\text { Urea } \mathrm{N} \text { reabsorption by the } \\
\text { kidney, } \mathrm{g} \cdot \mathrm{kg}^{-1} \mathrm{BW}^{0.75} \cdot \mathrm{d}^{-1}\end{array}$} & $\mathrm{~F}$ & 0.9 & 1.0 & 1.3 & 1.2 & 0.23 & 0.03 & 0.04 & 0.69 & 0.73 \\
\hline & $\mathrm{T}$ & 1.4 & 1.6 & 1.4 & 2.0 & & & $0.88^{\mathrm{x}}$ & $0.34^{\mathrm{x}}$ & $0.16^{\mathrm{x}}$ \\
\hline \multirow{2}{*}{$\begin{array}{l}\text { Renal urea } \mathrm{N} \text { reabsorption } \\
\text { rate, } \%\end{array}$} & F & 93.2 & 80.4 & 75.0 & 67.0 & 2.12 & 0.04 & $<0.001$ & 0.18 & 0.98 \\
\hline & $\mathrm{T}$ & 96.8 & 89.4 & 79.5 & 77.0 & & & $0.36^{\mathrm{x}}$ & $0.93^{\mathrm{x}}$ & $0.21^{\mathrm{x}}$ \\
\hline
\end{tabular}

a,b Within a column, means without a common superscript differ $(P<0.05)$.

${ }^{1} \mathrm{~N}-\mathrm{L}=$ linear effect of dietary $\mathrm{N} ; \mathrm{N}-\mathrm{Q}=$ quadratic effect of dietary $\mathrm{N} ; \mathrm{N}-\mathrm{C}=$ cubic effect of dietary $\mathrm{N}$.

${ }^{\mathrm{x}} P$-value for interaction of dietary $\mathrm{N}$ effect with breed.

dietary $\mathrm{N} \times$ breed; $P<0.01$ ). The GER:UER ratio was greater in the Tibetan than fine-wool sheep at the lowest $\mathrm{N}$ diet, and the reverse result occurred when sheep were fed the highest- $\mathrm{N}$ diet (linear dietary $\mathrm{N} \times$ breed; $P<0.05)$. The UUA:GER ratio tended to be greater in the Tibetan than fine-wool sheep $(P=0.07)$.

The UER, GER, UUE, ROC, and UUA each increased linearly with dietary N $(P<0.01)$. The UFE, UFE:GER, and GER:UER decreased linearly as dietary $\mathrm{N}$ content increased $(P<0.05)$. For ROC:GER and UUA:GER, cubic dietary $\mathrm{N} \times$ breed interactions were observed $(P<0.05)$ because Tibetan sheep demonstrated a greater ROC:GER ratio and a lower UUA:GER ratio when fed the diet with $23.1 \mathrm{~g} \mathrm{~N} / \mathrm{kg} \mathrm{DM}$, whereas fine-wool sheep did not show these cubic responses.

\section{Urea $N$ and Creatinine Concentrations in Plasma, Creatinine Clearance, and Urea N Reabsorption by the Kidney}

The urinary creatinine excretion of the Tibetan sheep was greater than that of the fine-wool sheep $(P<$ $0.05)$, and the renal creatinine clearance in the Tibetan sheep tended to be greater than in the fine-wool sheep $(P=0.09)$, but no difference between breeds was detected for plasma creatinine concentration $(P=0.43$; Table 4). The PUN was greater in Tibetan than finewool sheep receiving 11.0 and $16.7 \mathrm{~g} \mathrm{~N} / \mathrm{kg} \mathrm{DM}$ diets but lower in Tibetan than fine-wool sheep for the $23.1 \mathrm{~g} \mathrm{~N} / \mathrm{kg}$ DM diet, and no difference was detected for the $29.2 \mathrm{~g} \mathrm{~N} / \mathrm{kg}$ DM diet (linear dietary $\mathrm{N} \times$ breed; $P<0.05)$. Urea $\mathrm{N}$ tubular load, urea $\mathrm{N}$ reabsorption, and fractional renal urea $\mathrm{N}$ reabsorption were greater in Tibetan than fine-wool sheep $(P<0.05)$.

Urinary creatinine excretion was not affected by dietary $\mathrm{N}$ content $(P=0.98)$, but the plasma creatinine concentration was linearly decreased when the dietary $\mathrm{N}$ increased $(P<0.01)$, and the renal creatinine clearance tended to increase linearly with the dietary N $(P=0.09)$. The PUN concentration increased linearly $(P<0.001)$ with dietary $\mathrm{N}$ level. The renal tubular load and reabsorption of urea $\mathrm{N}$ increased linearly with the level of dietary $\mathrm{N}$ increased $(P<0.05)$, accompanied by a decline in fractional renal urea $\mathrm{N}$ reabsorption $(P<0.001)$.

\section{Urea N Pool Size, Urea Clearance, and Turnover Time}

As shown in Table 5, the urea $\mathrm{N}$ pool size was greater in Tibetan sheep when the diets containing 11.0 and $16.7 \mathrm{~g} \mathrm{~N} / \mathrm{kg}$ DM were fed, but it was similar between breeds for 23.1 and $29.2 \mathrm{~g} \mathrm{~N} / \mathrm{kg} \mathrm{DM}$ diets (linear dietary $\mathrm{N} \times$ breed; $P \leq 0.05$ ). The urea $\mathrm{N}$ pool turnover time tended to be shorter and GIT urea $\mathrm{N}$ clearance tended to be greater in the fine-wool than Tibetan sheep $(P<0.10)$. There was no difference between breeds observed for kidney urea $\mathrm{N}$ clearance $(P=0.49)$.

The urea $\mathrm{N}$ pool size increased linearly, whereas its turnover time decreased linearly as dietary $\mathrm{N}$ increased $(P<0.001)$. The urea $\mathrm{N}$ clearance by the kidney $(P<0.001)$ increased linearly with dietary $\mathrm{N}$, whereas the clearance of urea $\mathrm{N}$ to the GIT was not affected by dietary $\mathrm{N}$ content $(P=0.89)$. 
Table 5. Effect of dietary $\mathrm{N}$ intake on urea $\mathrm{N}$ pool size, turnover time, and urea $\mathrm{N}$ clearance in Tibetan $(\mathrm{T})$ and fine-wool sheep (F)

\begin{tabular}{|c|c|c|c|c|c|c|c|c|c|c|}
\hline \multirow[b]{2}{*}{ Item } & \multirow[b]{2}{*}{ Breed } & \multicolumn{4}{|c|}{ Dietary $N, \mathrm{~g} / \mathrm{kg}$ DM } & \multirow[b]{2}{*}{ SEM } & \multicolumn{4}{|c|}{$P$-value ${ }^{1}$} \\
\hline & & 11.0 & 16.7 & 23.1 & 29.2 & & Breed & N-L & $\mathrm{N}-\mathrm{Q}$ & $\mathrm{N}-\mathrm{C}$ \\
\hline \multirow{2}{*}{$\begin{array}{l}\text { Urea N pool size, } \\
\mathrm{g}\end{array}$} & $\mathrm{F}$ & $3.7^{\mathrm{a}}$ & $4.5^{\mathrm{a}}$ & $6.1^{\mathrm{a}}$ & $6.4^{\mathrm{a}}$ & \multirow[t]{2}{*}{0.51} & \multirow[t]{2}{*}{0.17} & $<0.001$ & 0.96 & 0.86 \\
\hline & $\mathrm{T}$ & $5.3^{\mathrm{b}}$ & $5.9^{\mathrm{b}}$ & $5.6^{\mathrm{a}}$ & $7.0^{\mathrm{a}}$ & & & $0.05^{\mathrm{x}}$ & $0.26^{\mathrm{x}}$ & $0.10^{\mathrm{x}}$ \\
\hline \multirow{2}{*}{$\begin{array}{l}\text { Turnover time, } \\
\min \end{array}$} & $\mathrm{F}$ & 424 & 280 & 295 & 215 & \multirow[t]{2}{*}{15.0} & \multirow[t]{2}{*}{0.06} & $<0.001$ & 0.09 & 0.70 \\
\hline & $\mathrm{T}$ & 506 & 424 & 284 & 273 & & & $0.20^{\mathrm{x}}$ & $0.93^{x}$ & $0.02^{\mathrm{x}}$ \\
\hline \multirow{2}{*}{$\begin{array}{l}\text { Kidney urea } \mathrm{N} \text { clearance, } \\
\mathrm{mL} / \mathrm{min}\end{array}$} & $\mathrm{F}$ & 5.0 & 16.2 & 18.2 & 27.8 & \multirow[t]{2}{*}{1.83} & \multirow[t]{2}{*}{0.49} & $<0.001$ & 0.57 & 0.27 \\
\hline & $\mathrm{T}$ & 3.2 & 10.5 & 20.7 & 27.3 & & & $0.20^{\mathrm{x}}$ & $0.81^{\mathrm{x}}$ & $0.02^{\mathrm{x}}$ \\
\hline \multirow{2}{*}{$\begin{array}{l}\text { Gastrointestinal tract } \\
\text { urea } \mathrm{N} \text { clearance, } \mathrm{mL} / \mathrm{min}\end{array}$} & $\mathrm{F}$ & 23.5 & 30.0 & 21.8 & 26.8 & \multirow[t]{2}{*}{2.11} & \multirow[t]{2}{*}{0.08} & 0.89 & 0.40 & 0.59 \\
\hline & $\mathrm{T}$ & 21.8 & 19.0 & 25.5 & 19.6 & & & $0.90^{\mathrm{x}}$ & $0.76^{\mathrm{x}}$ & $<0.001^{\mathrm{x}}$ \\
\hline
\end{tabular}

a,b Within a column, means without a common superscript differ $(P<0.05)$.

${ }^{\mathrm{x}} P$-value for interaction of dietary $\mathrm{N}$ effect with breed.

${ }^{1} \mathrm{~N}-\mathrm{L}=$ linear effect of dietary $\mathrm{N} ; \mathrm{N}-\mathrm{Q}=$ quadratic effect of dietary $\mathrm{N} ; \mathrm{N}-\mathrm{C}=$ cubic effect of dietary $\mathrm{N}$.

\section{DISCUSSION}

To date, physiological adaptation to inadequate $\mathrm{N}$ resources and feed supply have been investigated in dairy cattle (Marini and Van Amburgh, 2003), beef cattle (Archibeque et al., 2001; Huntington et al., 2009; Titgemeyer et al., 2012), yak (Guo et al., 2012), sheep (Sarraseca et al., 1998; Lobley et al., 2000; Marini et al., 2004), and goats (Brun-Bellut, 1997). The efficiency of $\mathrm{N}$ utilization and the ability of the animal to adapt to low $\mathrm{N}$ diets is affected by various factors, such as the dietary energy content, $\mathrm{N}$ digestion, urea kinetics, rumen microbial activity, urea reabsorption by the kidney, the physiological state of the animal, and animal species (Wang et al., 2011; Marini et al., 2004).

\section{Nitrogen Balance and the Influence of a Low-N Diet}

As dietary protein supply increased, fine-wool sheep continued to increase protein deposition, which might be due to supply of limiting AA. In contrast, the Tibetan sheep did not demonstrate as robust a response to increases in dietary $\mathrm{N}$, which may reflect different genetic potential to respond to increased protein supply.

Although the $11.0 \mathrm{~g} \mathrm{~N} / \mathrm{kg} \mathrm{DM}$ diet in the present study was designed to provide less $\mathrm{N}$ than required for maintenance, sheep on this diet maintained a positive $\mathrm{N}$ balance, and the $\mathrm{N}$ retention of Tibetan sheep was significantly greater than that of fine-wool sheep. The NRC (1985) proposed a maintenance $\mathrm{N}$ requirement of $14.24 \mathrm{~g} / \mathrm{d}$ for $50-\mathrm{kg}$ sheep, but the present study found that $\mathrm{N}$ retention was $2.7 \mathrm{~g} / \mathrm{d}$ for Tibetan sheep and $2.0 \mathrm{~g} / \mathrm{d}$ for fine-wool sheep fed diets with $11.0 \mathrm{~g} \mathrm{~N} / \mathrm{kg}$ $\mathrm{DM}$, for which $\mathrm{N}$ intake was only $10.9 \mathrm{~g} / \mathrm{d}$. This indicates that the maintenance $\mathrm{N}$ requirement of our sheep might be lower than that proposed by the NRC (1985). This observation of low maintenance $\mathrm{N}$ requirements of Tibetan sheep could reflect selection for sheep with an ability to adapt to the harsh forage environment on the Qinghai-Tibetan Plateau similar to that observed in yaks (Heath et al., 1984; Wang et al., 2009). Although $\mathrm{N}$ retention was lower for fine-wool sheep than for Tibetan sheep fed the $11.0 \mathrm{~g} \mathrm{~N} / \mathrm{kg}$ DM diet, fine-wool sheep also showed a $\mathrm{N}$ maintenance requirement less than suggested by NRC (1985), perhaps indicating that the fine-wool sheep inherited some adaptive characteristics of the Tibetan sheep or that there has been selection for the ability to tolerate the low-N diets during the $40 \mathrm{yr}$ that fine-wool sheep have been raised in an environment providing periods of low $\mathrm{N}$ availability.

The $\mathrm{N}$ retention data demonstrated that Tibetan sheep were more adaptable to low dietary $\mathrm{N}$ than fine-wool sheep, but fine-wool sheep were more efficient in using dietary $\mathrm{N}$ when they received a high level of dietary $\mathrm{N}$, suggesting that the fine-wool sheep could be grown more quickly if supplied with high-protein diets, whereas the Tibetan sheep are more suitable to lower-protein diets.

Under traditional Tibetan grazing management, the daily $\mathrm{N}$ intake for $50-\mathrm{kg}$ Tibetan sheep gradually decreases from $38.5 \mathrm{~g} / \mathrm{d}$ in summer to $7.9 \mathrm{~g} / \mathrm{d}$ in early spring (Dan et al., 2009); our N intakes were designed to roughly represent dietary $\mathrm{N}$ of grazing sheep across all seasons. Normally, the dry and cold season on the Qinghai-Tibetan Plateau lasts for more than $5 \mathrm{mo}$, and during this time the quality of the forage is low, and the quantity is insufficient. Therefore, livestock without a good $\mathrm{N}$ salvage mechanism are at increased risk of death. Our research shows that $\mathrm{N}$ retention under a low$\mathrm{N}$ diet (11.0 and $16.7 \mathrm{~g} / \mathrm{kg} \mathrm{DM}$ ) was better in Tibetan sheep than in fine-wool sheep, indicating that the established Tibetan sheep made more efficient use of dietary $\mathrm{N}$ than the more recently introduced fine-wool sheep when they were fed a low-N diet. Fine-wool sheep are normally provided with supplementary feed in the winter and early spring, whereas Tibetan sheep just graze on grassland all year round; differences between breeds 
in $\mathrm{N}$ utilization suggest that the different winter feeding regimens represent reasonable approaches to optimizing utilization of feed resources.

Although the results of the urea kinetics were matched with $\mathrm{N}$ retention for the $11.0 \mathrm{~g} \mathrm{~N} / \mathrm{kg}$ diet, a contradictory response occurred for the $16.7 \mathrm{~g} \mathrm{~N} / \mathrm{kg}$ diet, which might be influenced by the postabsorptive utilization of nutrients. The greater $\mathrm{N}$ retention for the Tibetan sheep than for the fine-wool sheep when the $16.7 \mathrm{~g} \mathrm{~N} /$ $\mathrm{kg}$ diet was fed could be due to the following reasons: 1) Tibetan sheep may have more efficient utilization of MP, perhaps because of differences between breeds in regulation of AA catabolism. 2) There may be differences in the type of proteins deposited, with fine-wool sheep likely producing more wool and less muscle than Tibetan sheep; the greater urinary creatinine excretion by Tibetan sheep suggests that muscle mass was greater for Tibetan sheep than for fine-wool sheep. 3) The energy requirements may be different between the breeds because the energy supply affects the efficiency of AA utilization in ruminants (Schroeder et al., 2006a,b); Tibetan sheep might have lower maintenance energy requirements, which could allow more energy for protein deposition and thereby improve the efficiency of protein use. It should be noted that $\mathrm{N}$ retention would include protein deposited both as muscle and wool.

In agreement with other studies (Marini et al., 2004; Wang et al., 2011), we observed adaptive changes in $\mathrm{N}$ metabolism when sheep were fed a low-N diet. Urinary $\mathrm{N}$, urinary urea $\mathrm{N}$, and the proportion of urea $\mathrm{N}$ in total excreted urinary $\mathrm{N}$ increased as dietary $\mathrm{N}$ increased (Ergene and Pickering, 1978; Leng et al., 1985; Tebot et al., 1998; Marini et al., 2004; Guo et al., 2012), indicating that the increase in urinary $\mathrm{N}$ was largely associated with increases in the urinary urea $\mathrm{N}$, especially when dietary $\mathrm{N}$ was sufficient (Titgemeyer et al., 2012).

Urinary urea $\mathrm{N}$ excretion when sheep were fed the diet with $29.2 \mathrm{~g} \mathrm{~N} / \mathrm{kg}$ DM was 11.8 and 9.2 times greater than that when sheep were fed the diet with $11.0 \mathrm{~g} \mathrm{~N} / \mathrm{kg}$ DM for Tibetan sheep and fine-wool sheep, respectively. Urea $\mathrm{N}$ accounted for $33.1 \%$ to $72.3 \%$ and $36.5 \%$ to $76.4 \%$ of urine $\mathrm{N}$ in Tibetan and fine-wool sheep, respectively. These results are similar to those of Marini et al. (2004) in lambs, where urea accounted for $28.6 \%, 71.0 \%$, and $81.2 \%$ of urine $\mathrm{N}$ when animals were fed diets containing 15.6, 28.7, and $40.5 \mathrm{~g} \mathrm{~N} / \mathrm{kg} \mathrm{DM}$, respectively.

\section{Dietary N Effect on Urea Kinetics between Breeds}

Urea $\mathrm{N}$ recycling has long been recognized as a mechanism by which animals can salvage $\mathrm{N}$ (Lobley et al., 2000). The intestinal AA supply to ruminants is mostly from the rumen microbial protein $(40 \%$ to $70 \%$;
Clark et al., 1992), of which $40 \%$ to $68 \%$ of the $\mathrm{N}$ is derived from rumen ammonia $\mathrm{N}$ (Hristov and Broderick, 1994). In the present study, the dietary energy was formulated to be isocaloric among diets, and $\mathrm{N}$ supply was likely first limiting for microbial protein synthesis when sheep were fed inadequate $\mathrm{N}$ diets. Greater UER and GER were observed for Tibetan sheep than for finewool sheep when the diet with $11.0 \mathrm{~g} \mathrm{~N} / \mathrm{kg} \mathrm{DM}$ was fed, so more AA might be supplied to the host by the rumen microbes in the Tibetan sheep. When large amounts of ammonia are absorbed across the rumen wall rather than being captured for microbial growth, use of recycled urea will be inefficient, which leads to increases in ROC (Lapierre and Lobley, 2001) and the opportunity for elimination as urinary urea N. Despite greater ROC for Tibetan than for fine-wool sheep fed the lowest protein diet, which might be expected to increase UUE, the amount of UUE was not different between breeds, which might be associated with the greater renal urea reabsorption rates observed for Tibetan than for fine-wool sheep. As a result, ROC might reenter the gut and supply more $\mathrm{N}$ to the ruminal microbes of Tibetan sheep, which could lead to the greater observed GER and GER:UER for Tibetan sheep than for fine-wool sheep when the diet with $11.0 \mathrm{~g} \mathrm{~N} / \mathrm{kg}$ DM was fed. The tendency for a greater ratio of UUA:GER in Tibetan than fine-wool sheep supports this concept.

The GER:UER ratio in Tibetan sheep (88\%) was greater than in fine-wool sheep (82\%) when they were fed the diet with $11.0 \mathrm{~g} \mathrm{~N} / \mathrm{kg} \mathrm{DM}(\mathrm{N}$ intake $=10.9$ $\mathrm{g} / \mathrm{d}$ ), and both were somewhat greater than that observed by Lobley et al. (2000) in sheep fed a hay-grass diet $(\mathrm{N}$ intake $=14.3 \mathrm{~g} / \mathrm{d}$; GER:UER $=70 \%)$ or a concentrate-forage diet $(\mathrm{N}$ intake $=17.1 \mathrm{~g} / \mathrm{d}$; GER:UER $=61 \%)$. This may reflect a greater ability of Tibetan and fine-wool sheep, relative to European breeds, to retrieve urea $\mathrm{N}$ when $\mathrm{N}$ intake is lower than required for growth. There are, however, a number of other factors that affect GER:UER ratios, and the urea kinetics of Tibetan and fine-wool sheep in our study were generally similar to those in previous reports with other sheep breeds. Our work does agree with previous studies that ruminants in general are quite adept at recycling urea when dietary $\mathrm{N}$ is low (Lapierre and Lobley, 2001; Wickersham et al., 2008a).

In agreement with other studies (Sarraseca et al., 1998; Archibeque et al., 2001; Sunny et al., 2007; Wickersham et al., 2008a,b), UER, UUE, GER, and ROC increased significantly as dietary $\mathrm{N}$ increased. In our research, UFE was decreased as the dietary $\mathrm{N}$ increased, which was consistent with the finding by Marini and Van Amburgh (2003) in heifers but was in contrast to other reports (Wickersham et al., 2008a; Bailey et al., 2012). In experiments where UFE decreased in response 
to increasing dietary $\mathrm{N}$, the higher levels of dietary $\mathrm{N}$ exceeded the ruminal requirement for $\mathrm{N}$, whereas in cases where UFE increased in response to increasing dietary protein, the higher levels of dietary protein did not exceed the ruminal $\mathrm{N}$ requirement. When the ruminal requirement is not exceeded, increases in dietary $\mathrm{N}$ will result in more capture of recycled urea $\mathrm{N}$ by the ruminal microbes (Wickersham et al., 2008a) and thus more of the urea $\mathrm{N}$ appearing in feces as undigested microbial residues. In contrast, when ruminal ammonia needs are already met by the diet, increases in dietary $\mathrm{N}$ provides excess ammonia to the rumen, which will be used in lieu of recycled urea $\mathrm{N}$, thereby decreasing microbial capture of recycled urea and the undigested microbial $\mathrm{N}$ in feces derived from GER.

The UER was greater than the amount of apparent digestible $\mathrm{N}$ when the sheep were fed the lowest-N diet $(11.0 \mathrm{~g} / \mathrm{kg} \mathrm{DM})$, but UER increased less rapidly than apparent digestible N, such that UER became less than apparent digestible $\mathrm{N}$ for the higher-N diets. Our ratios of UER to apparent digestible $\mathrm{N}$ for sheep fed the diet with $11.0 \mathrm{~g} \mathrm{~N} / \mathrm{kg}$ DM were within the range of sheep fed low$\mathrm{N}$ diets (Sarraseca et al., 1998; Lobley et al., 2000).

\section{Urinary Creatinine Excretion, Plasma Urea N Concentration, Renal Urea N Reabsorption, and Glomerular Filtration Rate}

Urinary creatinine excretion was not affected by dietary N content within breed (Marini et al., 2004; Wang et al., 2009), such that it can be used as an appropriate marker of glomerular filtration rate (Wang et al., 2009). Creatinine excretion, however, is associated with BW (Fiems et al., 1997), muscle content (Van Niekerk et al., 1963; Zanton and Heinrichs, 2009), and hormonal status (Wang et al., 2009) of animals. In our study, more urinary creatinine excretion was observed in Tibetan sheep than in fine-wool sheep, indicating that Tibetan sheep contained more muscle than the fine-wool sheep. The glomerular filtration rate of the Tibetan sheep was greater than that of the fine-wool sheep, which would lead to a greater urea $\mathrm{N}$ tubular load; however, because of more efficient urea $\mathrm{N}$ reabsorption in the Tibetan sheep there were no differences between breeds in urinary urea $\mathrm{N}$ excretion.

As reported by Sunny et al. (2007), the transfer of urea $\mathrm{N}$ to the GIT was highly related to PUN concentration, so GER increased with the elevation of PUN. The concentration of PUN of Tibetan sheep was greater than that for fine-wool sheep when they were fed the diet with $11.0 \mathrm{~g} \mathrm{~N} / \mathrm{kg} \mathrm{DM}$, as was GER. The PUN in our sheep was similar to concentrations reported in yaks fed restricted diets (10.4 mM, Wang et al., 2011; $16.4 \mathrm{mM}$, Long et al., 1999) but greater than concentrations reported in other ruminants fed diets with restricted $\mathrm{N}$ content $(4.4 \mathrm{mM}$, Ferrell et al., 1999; $2.6 \mathrm{mM}$, Sunny et al., 2007; $1.6 \mathrm{mM}$, Muscher et al., 2010). Normally, a high concentration of PUN leads to more urea $\mathrm{N}$ excreted in the urine, but little UUE was detected in our sheep fed the low-protein diet, supporting the high rates of renal urea reabsorption previously discussed. The specific urea transporters in ruminant kidney and gut tissues (Marini and Van Amburgh, 2003; Marini et al., 2004; Artagaveytia et al., 2005) are considered regulatory mechanisms for partitioning of urea between recycling and urinary excretion. In our study, the greater GER:UER ratio, plasma urea $\mathrm{N}$ concentration, and renal reabsorption rate in Tibetan than fine-wool sheep fed the $11.0 \mathrm{~g} \mathrm{~N} / \mathrm{kg}$ DM diet are probably related to the regulation of expression or activity of these urea transporters, but further investigations would be required to evaluate those effects.

Changes in renal urea $\mathrm{N}$ reabsorption in relation to the $\mathrm{N}$ content of the diet were consistent with existing reports (Tebot et al., 1998; Marini et al., 2004); renal tubular load of urea $\mathrm{N}$ increased, whereas the proportion of urea $\mathrm{N}$ reabsorbed decreased, with increasing dietary N. Schmidt-Nielsen et al. (1958) reported that urea reabsorption rose when animals were fed low $\mathrm{N}$ diets, and Isozaki et al. (1994) characterized the involvement of the kidney in this phenomenon in rats.

\section{Effect of N Intake on Urea Pool Size and Urea Clearance by the Kidney and GIT}

Compared with the fine-wool sheep, the Tibetan sheep had greater urea pool size when receiving the 11.0 and $16.7 \mathrm{~g} \mathrm{~N} / \mathrm{kg}$ DM diets, which was due to the higher PUN and a bit heavier BW of the Tibetan sheep. Like in previous reports (Marini and Van Amburgh, 2003; Guo et al., 2012), we observed that the urea pool size became smaller as the level of dietary $\mathrm{N}$ decreased. In contrast, turnover time decreased with increasing dietary $\mathrm{N}$, reflecting increases in GER and kidney urea clearance as dietary $\mathrm{N}$ increased.

When animals were fed a low-N diet, some regulatory mechanism salvaged the recycled $\mathrm{N}$ to help maintain $\mathrm{N}$ balance by reducing urea clearance by the kidney and increasing the percentage of urea cleared to the GIT (Kennedy and Milligan, 1980). In the present study, increasing the amount of $\mathrm{N}$ in the diet resulted in a typical physiological response, namely, that kidney urea clearance increased while the percentage of urea clearance to the GIT (GER:UER) decreased despite increases in the amount of urea cleared to the GIT (GER). 


\section{Conclusion}

Our data indicated that Tibetan sheep retained dietary $\mathrm{N}$ more efficiently than introduced fine-wool sheep when dietary $\mathrm{N}$ was insufficient but that finewool sheep retained more $\mathrm{N}$ when a high level of dietary $\mathrm{N}$ was provided. Tibetan sheep were characterized by renal urea $\mathrm{N}$ reabsorption rates that were greater than those of the introduced fine-wool sheep. This difference contributed to greater PUN concentrations, UER, GER, and ROC for Tibetan than fine-wool sheep when dietary $\mathrm{N}$ was low.

\section{LITERATURE CITED}

AOAC. 1990. Official methods of analysis. 16th ed. Assoc. Off. Anal. Chem., Arlington, VA.

Archibeque, S. L., J. C. Burns, and G. B. Huntington. 2001. Urea flux in beef steers: Effects of forage species and nitrogen fertilization. J. Anim. Sci. 79:1937-1943.

Artagaveytia, N., J. M. Elalouf, C. de Rouffignac, R. Boivin, and A. Cirio. 2005. Expression of urea transporter (UT-A) mRNA in papilla and pelvic epithelium of kidney in normal and low protein fed sheep. Comp. Biochem. Phys. B Biochem. Mol. Biol. 140:279-285.

Broderick, G. A., and J. H. Kang. 1980. Automated simultaneous determination of ammonia and total amino acids in ruminal fluid and in vitro media. J. Dairy Sci. 63:64-75. doi:10.3168/ jds.S0022-0302(80)82888-8.

Bailey, E. A., E. C. Titgemeyer, K. C. Olson, D. W. Brake, M. L. Jones, and D. E. Anderson. 2012. Effects of supplemental energy and protein on forage digestion and urea kinetics in growing beef cattle. J. Anim. Sci. 90:3492-3504. doi:10.2527/jas.2011-4458.

Balcells, J., J.A. Guada, J. M. Peiro, and D. S. Parker. 1992. Simultaneous determination of allantoin and oxypurines in biological fluids by high-performance liquid chromatography. J. Chromatogr. A 575:153-157. doi:10.1016/0378-4347(92)80517-T.

Bartle, S. J., O. A. Turgeon Jr., R. L. Preston, and D. R. Brink. 1988. Procedural and mathematical considerations in urea dilution estimation of body composition in lambs. J. Anim. Sci. 66:1920-1927.

Brun-Bellut, J. 1997. Urea recycling in the rumen of dairy goats: Effects of physiological stage and composition of intake. Small Rumin. Res. 23:83-90. doi:10.1016/S0921-4488(96)00910-8.

Clark, J. H., T. H. Klusmeyer, and M. R. Cameron. 1992. Microbial protein synthesis and flows of nitrogen fractions to the duodenum of dairy cows. J. Dairy Sci. 75:2304-2323. doi:10.3168/ jds.S0022-0302(92)77992-2.

Dan, R. F., R. J. Long, H. T. Zhang, X. Zhang, and X. Z. Ding. 2009. Analysis of rumen bacterial flora of Tibetan sheep with seasonal shift. Chin. J. Anim. Nutr. 21(5):798-802.

Ergene, N., and E. C. Pickering. 1978. The effects of reducing dietary nitrogen and of increasing sodium chloride intake on urea excretion and reabsorption and on urea osmolality in sheep. Q. J. Exp. Physiol. Cogn. Med. Sci. 63:67-76.

Ferrell, C. L., K. K. Kreikemeier, and H. C. Freetly. 1999. The effect of supplemental energy, nitrogen, and protein on feed intake, digestibility, and nitrogen flux across the gut and liver in sheep fed low-quality forage. J. Anim. Sci. 77:3353-3364.
Fiems, L. Q., B. G. Cottyn, Q. F. Boucque, and C. Bogaerts. 1997. Effect of beef type, body weight and dietary protein content on voluntary feed intake, digestibility, blood and urine metabolites and nitrogen retention. J. Anim. Physiol. Anim. Nutr. (Berl.) 77:1-9. doi:10.1111/j.1439-0396.1997.tb00731.x.

Gerald, W. N., J. L. Han, and R. J. Long. 2003. The Yak. 2nd ed. Reg. Off. Asia Pac., Food Agric. Organ., United Nations, Bangkok, Thailand.

Guo, X. S., Y. Zhang, J. W. Zhou, R. J. Long, G. S. Xin, B. Qi, L. M. Ding, and H. C. Wang. 2012. Nitrogen metabolism and recycling in yaks (Bos grunniens) offered a forage-concentrate diet differing in N concentration. Anim. Prod. 52:287-296. doi:10.1071/AN11208.

Harmeyer, J., and H. Martens. 1980. Aspects of urea metabolism in ruminants with reference to the goat. J. Dairy Sci. 63:1707-1728. doi:10.3168/jds.S0022-0302(80)83132-8.

Heath, D., D. Williams, and J. Dickinson. 1984. The pulmonary arteries of the yak. Cardiovasc. Res. 18(3):133-139. doi:10.1093/cvr/18.3.133.

Hristov, A., and G. A. Broderick. 1994. In vitro determination of ruminal protein degradability using $\left[{ }^{15} \mathrm{~N}\right]$ ammonia to correct for microbial nitrogen uptake. J. Anim. Sci. 72:1344-1354.

Huntington, G. B., K. Magee, A. Matthews, M. Poore, and J. Burns. 2009. Urea metabolism in beef steers fed tall fescue, orchardgrass, or gamagrass hays. J. Anim. Sci. 87:13461353. doi:10.2527/jas.2008-1444.

Isozaki, T., A. G. Gillin, C. E. Swanson, and J. M. Sands. 1994. Protein restriction sequentially induces new urea transport processes in rat initial IMCD. Am. J. Physiol. 266:F756-F761.

Kennedy, P. M., and L. P. Milligan. 1980. The degradation and utilization of endogenous urea in the gastrointestinal tract of ruminant: A review. Can. J. Anim. Sci. 60:205-221. doi:10.4141/cjas80-030.

Lapierre, H., and G. E. Lobley. 2001. Nitrogen recycling in the ruminant: A review. J. Dairy Sci. 84:E223-E236. doi:10.3168/ jds.S0022-0302(01)70222-6.

Leng, L., M. Szanyiova, and K. Boda. 1985. The renal response of sheep to a low dietary nitrogen intake. Physiol. Bohemoslov. 34:147-154.

Lobley, G. E., D. M. Bremmer, and G. Zuur. 2000. Effects of diet quality on urea fates in sheep as assessed by refined, noninvasive $\left[{ }^{15} \mathrm{~N}^{15} \mathrm{~N}\right]$ urea kinetics. Br. J. Nutr. 84:459-468.

Long, R. J., S. K. Dong, Z. Z. Hu, J. J. Shi, Q. M. Dong, and X. T. Han. 2004. Digestibility, nutrient balance and urinary purine derivative excretion in dry yak cows fed oat hay at different levels of intake. Livest. Prod. Sci. 88:27-32. doi:10.1016/j.livprodsci.2003.11.004.

Long, R. J., S. K. Dong, X. H. Wei, and X. P. Pu. 2005. The effect of supplementary feeds on the bodyweight of yaks in cold season. Livest. Prod. Sci. 93:197-204. doi:10.1016/j.livprodsci.2004.08.016.

Long, R. J., D. G. Zhang, X. Wang, Z. Z. Hu, and S. K. Dong. 1999. Effect of strategic feed supplementation on productive and reproductive performance in yak cows. Prev. Vet. Med. 38:195-206. doi:10.1016/S0167-5877(98)00125-1.

Marini, J. C., and M. S. Attene-Ramos. 2006. An improved analytical method for the determination of urea nitrogen isotopomers in biological samples utilizing continuous flow isotope ratio mass spectrometry. Rapid Commun. Mass Spectrom. 20:3736-3740. doi:10.1002/rcm.2788.

Marini, J. C., J. D. Klein, J. M. Sands, and M. E. Van Amburgh. 2004. Effect of nitrogen intake on nitrogen recycling and urea transporter abundance in lambs. J. Anim. Sci. 82:1157-1164.

Marini, J. C., and M. E. Van Amburgh. 2003. Nitrogen metabolism and recycling in Holstein heifers. J. Anim. Sci. 81:545-552. 
Marsh, W. H., B. Fingerhut, and E. Kirsch. 1957. Determination of urea $\mathrm{N}$ with the diacetyl method and an automatic dialyzing apparatus. Am. J. Clin. Pathol. 8:681-688.

Muscher, A. S., B. Schroder, G. Breves, and K. Huber. 2010. Dietary nitrogen reduction enhances urea transport across goat rumen epithelium. J. Anim. Sci. 88:3390-3398. doi:10.2527/jas.2010-2949.

NRC. 1985. Nutrient requirements of sheep. 6th rev. ed. Natl. Acad. Press, Washington, DC.

Reynolds, C. K., H. F. Tyrrell, and P. J. Reynolds. 1991. Effects of diet forage-to-concentrate ratio and intake on energy metabolism in growing beef heifers: Net nutrient metabolism by visceral tissues. J. Nutr. 121:1004-1015.

Sarraseca, A., E. Milne, M. J. Metcalf, and G. E. Lobley. 1998. Urea recycling in sheep: Effects of intake. Br. J. Nutr. 79:7988. doi:10.1079/BJN19980011.

Schmidt-Nielsen, B., H. Osaki, H. V. Murdaugh, and R. O’Dell. 1958. Renal regulation of urea excretion in sheep. Am. J. Physiol. 194:221-228.

Schroeder, G. F., E. C. Titgemeyer, M. S. Awawdeh, J. S. Smith, and D. P. Gnad. 2006a. Effect of energy level on methionine utilization by growing steers. J. Anim. Sci. 84:1497-1504.

Schroeder, G. F., E. C. Titgemeyer, M. S. Awawdeh, J. S. Smith, and D. P. Gnad. 2006b. Effects of energy source on methionine utilization by growing steers. J. Anim. Sci. 84:1505-1511.

Shao, B. P., R. J. Long, Y. P. Ding, J. L. Wang, L. M. Ding, and H. C. Wang. 2010. Morphological adaptation of yak (Bos grunniens) tongue to the foraging environment of the Qinghai-Tibetan Plateau. J. Anim. Sci. 88:2594-2603. doi:10.2527/jas.2009-2398.

Sunny, N. E., S. L. Owens, R. L. Baldwin, S. W. El-Kadi, R. A. Kohn, and B. J. Bequette. 2007. Salvage of blood urea nitrogen in sheep is highly dependent on plasma urea concentration and efficiency of capture within the digestive tract. J. Anim. Sci. 85:1006-1013. doi:10.2527/jas.2006-548.
Tebot, I., S. Faix, M. Szanyiova, A. Cirio, and L. Leng. 1998. Micropuncture study on urea movements in the kidney cortical tubules of low protein fed sheep. Vet. Res. 29:99-105.

Titgemeyer, E. C., K. S. Spivey, S. L. Parr, D. W. Brake, and M. L. Jones. 2012. Relationship of whole body nitrogen utilization to urea kinetics in growing steers. J. Anim. Sci. 90:35153526. doi:10.2527/jas.2011-4621.

Van Niekerk, B. D. H., A. Bensadoun, O. L. Paladines, and J. T. Reid. 1963. A study of some of conditions affecting the rate of excretion and stability of creatinine in sheep urine. J. Nutr. 79:373-380.

Van Soest, P. J., J. B. Robertson, and B. A. Lewis. 1991. Methods for dietary fiber, neutral detergent fiber, and non-starch polysaccharides in relation to animal nutrition. J. Dairy Sci. 74:3583-3597. doi:10.3168/jds.S0022-0302(91)78551-2.

Wang, H., R. Long, W. Zhou, X. Li, J. Zhou, and X. Guo. 2009. A comparative study on urinary purine derivative excretion for yak, indigenous cattle and crossbred in the Qinghai-Tibetan plateau, China. J. Anim. Sci. 87:2355-2362. doi:10.2527/jas.2008-1544.

Wang, H. C., R. J. Long, J. B. Liang, X. S. Guo, L. M. Ding, and Z. H. Shang. 2011. Comparison of nitrogen metabolism in yak (Bos grunniens) and indigenous cattle (Bos taurus) on the QinghaiTibetan Plateau. Asian-Australas. J. Anim. Sci. 24:766-773.

Wickersham, T.A., E.C. Titgemeyer, R. C. Cochran, E. E. Wickersham, and D. P. Gnad. 2008a. Effect of rumen-degradable intake protein supplementation on urea kinetics and microbial use of recycled urea in steers consuming low-quality forage. J. Anim. Sci. 86:3079-3088. doi:10.2527/jas.2007-0325.

Wickersham, T. A., E. C. Titgemeyer, R. C. Cochran, E. E. Wickersham, and E. S. Moore. 2008b. Effect of frequency and amount of rumendegradable intake protein supplementation on urea kinetics and microbial use of recycled urea in steers consuming low-quality forage. J. Anim. Sci. 86:3089-3099. doi:10.2527/jas.2007-0326.

Zanton, G. I., and A. J. Heinrichs. 2009. Digestion and nitrogen utilization in dairy heifers limit-fed a low or high forage ration at four levels of nitrogen intake. J. Dairy Sci. 92:20782094. doi:10.3168/jds.2008-1712. 
Reproduced with permission of the copyright owner. Further reproduction prohibited without permission. 